University of Nebraska - Lincoln

DigitalCommons@University of Nebraska - Lincoln

Development of a simplistic vegetative filter strip model for sediment and nutrient retention at the field scale

Michael J. White

USDA-ARS, mike.white@ars.usda.gov

Jeff G. Arnold

USDA-ARS, jeff.arnold@ars.usda.gov

Follow this and additional works at: https://digitalcommons.unl.edu/usdaarsfacpub

Part of the Agricultural Science Commons

White, Michael J. and Arnold, Jeff G., "Development of a simplistic vegetative filter strip model for sediment and nutrient retention at the field scale" (2009). Publications from USDA-ARS / UNL Faculty. 1067.

https://digitalcommons.unl.edu/usdaarsfacpub/1067

This Article is brought to you for free and open access by the U.S. Department of Agriculture: Agricultural Research Service, Lincoln, Nebraska at DigitalCommons@University of Nebraska - Lincoln. It has been accepted for inclusion in Publications from USDA-ARS / UNL Faculty by an authorized administrator of DigitalCommons@University of Nebraska - Lincoln. 


\title{
Development of a simplistic vegetative filter strip model for sediment and nutrient retention at the field scale ${ }^{\dagger}$
}

\author{
Michael J. White* and Jeff G. Arnold \\ USDA-ARS Grassland, Soil, and Water Research Laboratory, Temple, Texas, USA
}

\begin{abstract}
:
Vegetative filter strips (VFSs) are a commonly used conservation measure to remove pollutants from agricultural runoff. The effectiveness of VFSs has been widely studied at the plot scale, yet researchers generally agree that field scale implementations are far less effective. The purpose of this research was to develop a field scale VFS submodel for the Soil and Water Assessment Tool (SWAT). A model for the retention of sediments and nutrients in VFSs was developed from experimental observations derived from 22 publications. A runoff retention model was developed from Vegetative Filter Strip MODel (VFSMOD) simulations. This model was adapted to operate at the field scale by considering the effects of flow concentration generally absent from plot scale experiments. Flow concentration through 10 hypothetical VFSs was evaluated using high resolution $(2 \mathrm{~m})$ topographical data and multipath flow accumulation. Significant flow concentration was predicted at all sites, on average $10 \%$ of the VFS received half of the field runoff. As implemented in SWAT, the VFS model contains two sections, a large section receiving relatively modest flow densities and a smaller section treating more concentrated flow. This field scale model was incorporated into SWAT and verified for proper function. This model enhances the ability of SWAT to evaluate the effectiveness of VFSs at the watershed scale. Published in 2009 by John Wiley \& Sons, Ltd.
\end{abstract}

KEY WORDS modelling; vegetative filter strip; SWAT; sediment; nutrients; conservation measures

Received 17 October 2008; Accepted 26 January 2009

\section{INTRODUCTION}

The evaluation of conservation measures at the watershed scale is highly desirable. In the USA, federally sponsored water quality programmes, such as the Conservation Reserve Program (CRP), Conservation Reserve Enhancement Program (CREP), Environmental Quality Incentives Program (EQIP), and various state programmes funded by Section 319(h) of the US Clean Water Act expend large quantities of resources often without quantitative assessments of water quality improvement. Assessment of US Department of Agriculture programmes is currently underway through the Conservation Effects Assessment Project (CEAP). Cost-effective evaluation of conservation measures at the watershed scale can be challenging. Monitoring approaches based on a paired watershed design (USEPA, 1993) are useful but are expensive and may be complicated by external factors. The application of measured conservation practice efficiencies from research fields or plot studies is common, but these methods cannot account for local conditions. Simulation models such as the Soil and Water Assessment Tool (SWAT; Arnold et al., 1998) have been accepted as surrogate measures to quantify the impacts of conservation programmes.

\footnotetext{
* Correspondence to: Michael J. White, USDA-ARS Grassland, Soil, and Water Research Laboratory, 808 East Blackland Road Temple, TX 76502, Temple, Texas, USA. E-mail: mike.white @ ars.usda.gov

$\dagger$ This article is a US Government work and is in the public domain in the USA.
}

The SWAT model is widely used to evaluate conservation practices at the watershed scale (Gassman et al., 2007); there are many examples in the published literature. Bracmort et al. (2006) used the SWAT model to evaluate the long term effectiveness of structural Best Management Practices (BMPs) on sediment and phosphorus. Vache et al. (2002) used the SWAT model to evaluate the effect of riparian buffers, engineered wetlands, grassed waterways, filter strips and field borders on nutrient and sediment losses from corn fields. Chu et al. (2005) used SWAT to simulate the effect of nonstructural BMPs including conservation tillage, no-till, contour farming and strip cropping. Arabi et al. (2008) evaluated crop rotation, cover crops, contour cropping, strip cropping, residue management, terracing, and field borders using SWAT.

One widely used conservation practice to remove agricultural and urban pollutants before reaching nearby water bodies is the vegetative filter strip (VFS). A VFS is a strip of dense vegetation located to intercept runoff from upslope pollutant sources and filter it. VFSs have gained popularity as a conservation practice due in part to the National Conservation Buffer Initiative, an effort to encourage the use of conservation buffers by agricultural producers by the Natural Resources Conservation Service (NRCS) (Helmers et al., 2005). The establishment of VFSs is subsidized by a variety of state and federal conservation programmes.

The SWAT model currently contains a VFS algorithm, but is has some limitations. It uses the same filtering efficiency for sediment and all nutrient forms. Differing 
trapping efficiencies have been observed between soluble and particulate nutrients (Goel et al., 2004). The current VFS model does not consider the effects of flow concentration apparent at the field and watershed scales. Due to widespread use of the SWAT to simulate VFSs (Chu et al., 2005; Arabi et al., 2008; Parajuli et al., 2008) improvements in these routines are needed.

The primary objective of this research was to develop an improved VFS sub-model for SWAT. The model was required to be applicable at the field scale, simple, and computationally efficient. Two separate research tasks were required to meet this objective. The first task was the development of a simple VFS model to predict sediment, nitrogen and phosphorus retention under uniform sheet flow conditions. The second was the adaptation of that model to account for nonuniformities in runoff distribution at the field scale. On-farm VFSs are not likely to be as effective as experimental studies due to flow concentration (Dillaha et al., 1989).

\section{VFS MODEL FOR UNIFORM FLOW CONDITIONS}

To evaluate the effectiveness of VFSs under ideal conditions, a model was developed from a combination of measured data derived from literature and Vegetative Filter Strip MODel (VFSMOD) (Muñoz-Carpena et al., 1999) simulations.

\section{Measured VFS performance database}

The potential effectiveness of VFSs is well established by many plot scale studies (Magette et al., 1989; Parsons et al., 1994; Barfield et al., 1998). Table I contains a summary of reported VFS effectiveness from 22 published studies. These studies were identified from a general search of the literature and other published summaries of VFS or riparian buffer effectiveness (Wenger, 1999; Helmers, 2003; Parkyn, 2004; Krutz et al., 2005; Mayer et al., 2005; Dorioz et al., 2006; Koelsch et al., 2006). Each publication in Table I was obtained to glean additional data not reported by other published summaries. Data were derived from both tables and figures, if necessary. Several parameters reported in Table I were calculated from measured data or estimates given in each publication.

The literature indicates that VFSs are highly effective; the average sediment removal was greater than $83 \%$. These data exhibit variable sediment trapping efficiencies ranging from $24 \%$ to $100 \%$ removal. On average, these studies may not represent the conditions under which VFSs are typically installed. Helmers et al. (2005) found many VFS studies to use buffers which cover a larger fraction of the field than NRCS installation guidelines suggest, perhaps overestimating their effectiveness. Although some researchers intentionally promoted concentrated flow in some experiments (Dillaha et al., 1989; Blanco-Canqui et al., 2006) the vast majority of experiments were conducted with uniform sheet flows. These data shown in Table I, generally represent VFS effectiveness under uniform sheet flow conditions.

\section{Simulated VFS database}

Despite the abundance of measured data in the literature on VFS effectiveness, these data were not entirely sufficient to understand the factors important to VFS function. Measured data are difficult and expensive to collect, and it is not feasible to measure VFS effectiveness under all conditions. In an effort to augment available measured VFS data, VFSMOD was used to predict changes in sediment and runoff removal efficiencies under a variety of conditions. VFSMOD was selected for this application over other VFS-related models due to its process-based nature, abundant documentation, and ease of use.

VFSMOD (Muñoz-Carpena et al., 1999) is a process based model which attempts to mimic runoff infiltration and sediment deposition within VFSs receiving uniform sheet flow. It is based on a sediment deposition in grass media model developed at the University of Kentucky with the addition of Green-Ampt infiltration and kinematic wave overland flow. VFSMOD was designed to make predictions under shallow uniform sheet flow conditions. Under these conditions the model has been validated successfully (Muñoz-Carpena 1999; Abu-Zreig et al., 2001). Abu-Zreig et al. (2001) found that VFSMOD could predict sediment retention much better $\left(R^{2} 0.62\right.$ vs. $\left.R^{2} 0.90\right)$ when measured flow widths were used as opposed to actual plot widths. This necessary adjustment demonstrates that VFSMOD predictions are contingent upon uniform flow conditions. VFSMOD was not a candidate for incorporation into SWAT. The algorithms used in VFSMOD are complex, requiring iterative solutions and significant computational resources. A watershed scale model, which may simulate many hundreds of VFS daily for decades, requires a less computationally intensive solution.

VFSMOD model and its companion program, UH, were used to generate a database of 1650 VFS simulations. The UH utility uses the curve number approach (USDA-SCS, 1972), unit hydrograph and the Modified Universal Soil Loss Equation (MUSLE) (Williams, 1975) to generate synthetic sediment and runoff loads from a source area upslope of the VFS (Muñoz-Carpena and Parsons, 2005). This simulation database contained $3 \mathrm{~h}$ rainfall events ranging from $10 \mathrm{~mm}$ to $100 \mathrm{~mm}$, on a cultivated field with a curve number of 85 and a $\mathrm{C}$ factor of $0 \cdot 1$. Field dimensions were fixed at $100 \mathrm{~m}$ by $10 \mathrm{~m}$ with a $10 \mathrm{~m}$ wide VFS at the downslope end. Width of the VFS ranged from $1 \mathrm{~m}$ to $20 \mathrm{~m}$ yielding drainage area to VFS area ratios from 5 to 100 . Slopes of $2 \%, 5 \%$ and $10 \%$ were simulated on 11 soil textural classes. This database was generated via software, which provided input parameters to both UH and VFSMOD then executed each program in turn. This database and a variety of other VFSMOD simulations were used to evaluate the sensitivity of various parameters and correlations between model inputs and predictions. 


\section{VFS parameterization}

The parameters used to specify a VFS in SWAT were an important consideration. VFS width has been correlated with effectiveness (Dijk et al., 1996; Barfield et al., 1998), but the parameterization of VFSs in SWAT using width is problematic. SWAT uses the Hydrologic Response Unit (HRU) concept in which a single simulation unit may be composed of non-contiguous geographic areas. A SWAT model may be composed of thousands of HRUs, each of which may represent a field, a portion of a field, or portions of many fields. Each HRU differs greatly in size, shape and connectivity. The use of the drainage area to VFS area ratio $\left(D A F S_{\text {ratio }}\right)$ instead of buffer width is attractive for incorporation into this watershed scale model framework. Using this ratio approach, HRU spatial distribution is less critical. A single $D A F S_{\text {ratio }}$ can be applied to many HRUs; no assumptions of HRU shape or size are required. Other researchers have correlated $D A F S_{\text {ratio }}$ with removal efficiency (Dosskey et al., 2002; Helmers

Table I. Vegetative filter strip effectiveness for sediment, runoff, nitrate, total nitrogen, total phosphorus and soluble phosphorus. Derived from 22 published studies

\begin{tabular}{|c|c|c|c|c|c|c|c|c|c|}
\hline \multirow[b]{2}{*}{ Source } & \multirow[b]{2}{*}{$\begin{array}{l}\text { Area } \\
\text { Ratio }\end{array}$} & \multirow[b]{2}{*}{$\begin{array}{l}\text { Sediment load } \\
\qquad\left(\mathrm{kg} / \mathrm{m}^{2}\right)\end{array}$} & \multirow[b]{2}{*}{$\begin{array}{l}\text { Runoff load } \\
(\mathrm{mm})\end{array}$} & \multicolumn{6}{|c|}{ Removal (\%) } \\
\hline & & & & Sediment & Runoff & Nitrate $\mathrm{N}$ & Total N & Total P & Soluble P \\
\hline \multirow[t]{7}{*}{ (a) } & - & $4 \cdot 0$ & 126 & 56 & 36 & - & - & - & - \\
\hline & - & $2 \cdot 2$ & 58 & 72 & 41 & - & - & - & - \\
\hline & - & $1 \cdot 3$ & 31 & 80 & 71 & - & - & - & - \\
\hline & - & 0.9 & 23 & 86 & 57 & - & - & - & - \\
\hline & - & 1.7 & 57 & 82 & 47 & - & - & - & - \\
\hline & - & 1.7 & 64 & 76 & 41 & - & - & - & - \\
\hline & - & $2 \cdot 3$ & 76 & 73 & 51 & - & - & - & - \\
\hline \multirow[t]{6}{*}{ (b) } & $30 \cdot 0$ & - & - & 85 & 71 & - & - & - & - \\
\hline & $30 \cdot 0$ & - & - & 76 & 44 & - & - & - & - \\
\hline & $30 \cdot 0$ & - & - & 90 & 79 & - & - & - & - \\
\hline & $15 \cdot 0$ & - & - & 91 & 83 & - & - & - & - \\
\hline & $15 \cdot 0$ & - & - & 83 & 73 & - & - & - & - \\
\hline & $15 \cdot 0$ & - & - & 88 & 65 & - & - & - & - \\
\hline \multirow{4}{*}{ (c) } & 1.6 & 3.0 & 132 & 100 & 92 & 97 & & 95 & \\
\hline & 11.4 & 11.7 & 655 & 80 & 13 & 35 & 49 & 51 & 43 \\
\hline & $2 \cdot 0$ & $2 \cdot 0$ & 115 & 93 & 21 & 70 & 77 & 80 & 77 \\
\hline & $1 \cdot 0$ & $1 \cdot 0$ & 57 & 97 & 33 & 83 & 87 & 93 & 86 \\
\hline \multirow[t]{5}{*}{ (d) } & 4.8 & $3 \cdot 8$ & 366 & 99 & 92 & 94 & - & 90 & - \\
\hline & $4 \cdot 8$ & $7 \cdot 8$ & 438 & 95 & 91 & 97 & - & 91 & - \\
\hline & $2 \cdot 4$ & $0 \cdot 6$ & 90 & 100 & 100 & 100 & - & 100 & - \\
\hline & 2.4 & $2 \cdot 8$ & 89 & 100 & 95 & 96 & - & 96 & - \\
\hline & $1 \cdot 6$ & $0 \cdot 2$ & 76 & 100 & 97 & 97 & - & 98 & - \\
\hline \multirow[t]{5}{*}{ (e) } & $1 \cdot 0$ & - & - & - & - & - & - & 67 & 65 \\
\hline & 0.5 & - & - & - & - & - & - & 71 & 74 \\
\hline & $0 \cdot 3$ & - & - & - & - & - & - & 87 & 89 \\
\hline & $0 \cdot 2$ & - & - & - & - & - & - & 91 & 93 \\
\hline & $0 \cdot 1$ & - & - & - & - & - & - & 92 & 94 \\
\hline \multirow[t]{5}{*}{ (f) } & 1.0 & - & - & - & - & - & - & 40 & 39 \\
\hline & 0.5 & - & - & - & - & - & - & 58 & 55 \\
\hline & $0 \cdot 3$ & - & - & - & - & - & - & 74 & 71 \\
\hline & $0 \cdot 2$ & - & - & - & - & - & - & 87 & 85 \\
\hline & $0 \cdot 1$ & - & - & - & - & - & - & 91 & 90 \\
\hline \multirow[t]{2}{*}{$(\mathrm{g})$} & $2 \cdot 5$ & - & - & 99 & 88 & - & - & - & - \\
\hline & 2.5 & - & - & 99 & 88 & - & - & - & - \\
\hline \multirow[t]{4}{*}{ (h) } & 1.5 & - & - & 97 & 78 & - & - & - & - \\
\hline & 1.5 & - & - & 99 & 92 & - & - & - & - \\
\hline & 4.0 & - & - & 95 & 66 & - & - & - & - \\
\hline & $4 \cdot 0$ & - & - & 98 & 86 & - & - & - & - \\
\hline \multirow[t]{8}{*}{ (i) } & $29 \cdot 0$ & - & - & 39 & - & 90 & - & 55 & 15 \\
\hline & 14.0 & - & - & 70 & - & 85 & - & 68 & 40 \\
\hline & $29 \cdot 0$ & - & - & 44 & - & 85 & - & 41 & 40 \\
\hline & $14 \cdot 0$ & - & - & 58 & - & 45 & - & 65 & 50 \\
\hline & $9 \cdot 6$ & - & - & 50 & - & 75 & - & 43 & $(\alpha)$ \\
\hline & $3 \cdot 7$ & - & - & 87 & - & 80 & - & 54 & $(\alpha)$ \\
\hline & $7 \cdot 6$ & - & - & 72 & - & 55 & - & 32 & 5 \\
\hline & 2.9 & - & - & 83 & - & 65 & - & 64 & 65 \\
\hline
\end{tabular}


Table I. (Continued)

\begin{tabular}{|c|c|c|c|c|c|c|c|c|c|}
\hline \multirow[b]{2}{*}{ Source } & \multirow[b]{2}{*}{$\begin{array}{l}\text { Area } \\
\text { Ratio }\end{array}$} & \multirow[b]{2}{*}{$\begin{array}{l}\text { Sediment load } \\
\left(\mathrm{kg} / \mathrm{m}^{2}\right)\end{array}$} & \multirow[b]{2}{*}{$\begin{array}{l}\text { Runoff load } \\
\text { (mm) }\end{array}$} & \multicolumn{6}{|c|}{ Removal (\%) } \\
\hline & & & & Sediment & Runoff & Nitrate $\mathrm{N}$ & Total N & Total P & Soluble P \\
\hline \multirow[t]{12}{*}{ (j) } & $2 \cdot 0$ & $3 \cdot 7$ & 50 & 99 & 74 & 81 & 92 & 95 & 78 \\
\hline & $2 \cdot 0$ & $4 \cdot 1$ & 92 & 96 & 55 & 76 & 90 & 90 & 26 \\
\hline & $4 \cdot 0$ & $7 \cdot 4$ & 100 & 90 & 2 & 32 & 76 & 80 & -31 \\
\hline & 4.0 & $8 \cdot 1$ & 184 & 82 & -24 & -13 & 54 & 65 & -119 \\
\hline & $2 \cdot 0$ & 8.5 & 46 & 83 & 0 & 52 & 70 & 72 & 43 \\
\hline & $2 \cdot 0$ & 9.4 & 66 & 58 & -72 & 3 & 42 & 60 & -258 \\
\hline & $4 \cdot 0$ & $16 \cdot 8$ & 92 & 73 & 9 & 54 & 65 & 67 & 43 \\
\hline & 4.0 & 18.5 & 132 & 34 & -48 & -22 & 23 & 35 & -100 \\
\hline & $2 \cdot 0$ & 1.3 & 36 & 93 & 65 & 81 & 89 & 89 & 71 \\
\hline & $2 \cdot 0$ & $2 \cdot 8$ & 84 & 93 & -55 & 67 & 76 & 86 & 30 \\
\hline & 4.0 & $2 \cdot 6$ & 72 & 86 & 72 & 84 & 88 & 86 & 79 \\
\hline & $4 \cdot 0$ & $5 \cdot 5$ & 168 & 81 & 63 & 66 & 80 & 84 & 60 \\
\hline \multirow[t]{4}{*}{ (k) } & $20 \cdot 0$ & - & - & 78 & 36 & 47 & 51 & 55 & 46 \\
\hline & $20 \cdot 0$ & - & - & 75 & 38 & 38 & 41 & 49 & 39 \\
\hline & $40 \cdot 0$ & - & - & 69 & 22 & 28 & 32 & 40 & 38 \\
\hline & $40 \cdot 0$ & - & - & 62 & 23 & 22 & 24 & 35 & 30 \\
\hline \multirow[t]{4}{*}{ (1) } & $3 \cdot 1$ & - & - & 70 & 7 & 61 & 64 & 67 & 43 \\
\hline & 1.4 & - & - & 94 & 17 & 88 & 90 & 93 & 85 \\
\hline & $3 \cdot 1$ & - & - & 70 & 10 & 41 & 50 & 46 & 27 \\
\hline & 1.4 & - & - & 92 & 21 & 68 & 73 & 81 & 34 \\
\hline \multirow[t]{3}{*}{ (m) } & $2 \cdot 0$ & - & - & 24 & - & -498 & - & 76 & 75 \\
\hline & 1.0 & - & - & 41 & - & -140 & - & 90 & 88 \\
\hline & 0.7 & - & - & 70 & - & -97 & - & 94 & 93 \\
\hline \multirow[t]{6}{*}{ (n) } & $2 \cdot 4$ & - & - & 80 & - & - & 51 & -25 & - \\
\hline & 2.4 & - & - & 89 & - & - & 46 & 58 & - \\
\hline & $2 \cdot 4$ & - & - & 56 & - & - & 22 & 21 & - \\
\hline & $4 \cdot 8$ & - & - & 65 & - & - & -77 & -101 & - \\
\hline & $4 \cdot 8$ & - & - & 66 & - & - & 36 & 59 & - \\
\hline & $4 \cdot 8$ & - & - & 25 & - & - & -12 & 34 & - \\
\hline \multirow[t]{9}{*}{ (o) } & - & $0 \cdot 2$ & 49 & 100 & - & - & 90 & 90 & - \\
\hline & - & 0.2 & 43 & 100 & - & - & 97 & 96 & - \\
\hline & - & 0.2 & 43 & 100 & - & - & 98 & 99 & - \\
\hline & - & $0 \cdot 2$ & 48 & 100 & - & - & 98 & 97 & - \\
\hline & - & $0 \cdot 2$ & 50 & 100 & - & - & 97 & 97 & - \\
\hline & - & $0 \cdot 3$ & 61 & 100 & - & - & 93 & 93 & - \\
\hline & - & $0 \cdot 3$ & 64 & 100 & - & - & 87 & 85 & - \\
\hline & - & $0 \cdot 3$ & 67 & 99 & - & - & 79 & 77 & - \\
\hline & - & 0.4 & 82 & 100 & - & - & 91 & 92 & - \\
\hline \multirow[t]{9}{*}{ (p) } & $9 \cdot 0$ & - & - & 89 & - & - & - & - & - \\
\hline & $27 \cdot 0$ & - & - & 91 & - & - & - & - & - \\
\hline & $9 \cdot 0$ & - & - & 98 & - & - & - & - & - \\
\hline & $9 \cdot 0$ & - & - & 97 & - & - & - & - & - \\
\hline & 4.5 & - & - & 93 & - & - & - & - & - \\
\hline & $13 \cdot 5$ & - & - & 77 & - & - & - & - & - \\
\hline & $9 \cdot 0$ & - & - & 57 & - & - & - & - & - \\
\hline & 4.5 & - & - & 93 & - & - & - & - & - \\
\hline & $9 \cdot 0$ & - & - & 89 & - & - & - & - & - \\
\hline \multirow[t]{2}{*}{ (q) } & $8 \cdot 6$ & 0.5 & 77 & 75 & 32 & - & - & 69 & 21 \\
\hline & 4.4 & $0 \cdot 3$ & 39 & 81 & 32 & - & - & 73 & 6 \\
\hline
\end{tabular}

et al., 2005; Mankin et al., 2006). In most plot scale studies, plot dimensions and VFS length were fixed, making $\mathrm{DAFS}_{\text {ratio }}$ and width interchangeable. At the field scale, $D A F S_{\text {ratio }}$ and VFS width may not be interchangeable because fields many not be rectangular. No measured data on VFS orientation (length: width ratio) could be identified.

To evaluate effects of orientation on trapping efficiency, a set of VFSMOD simulations were performed using a $50 \mathrm{~mm}$ rainfall event on a silt loam soil with a $4 \%$ slope. VFS length and width ranged from $1 \mathrm{~m}$ to $10 \mathrm{~m}$ but the total area was fixed at $10 \mathrm{~m}^{2}$ $\left(D A F S_{\text {ratio }}=10\right)$. Efficiencies were only mildly affected by orientation, ranging from $51.2 \%$ to $53.5 \%$, and $4.9 \%$ to $5.5 \%$ for sediment and runoff respectively. VFS effectiveness was relatively insensitive to orientation, further justifying the use of $D A F S_{\text {ratio }}$ over VFS width. 
Table I. (Continued)

\begin{tabular}{|c|c|c|c|c|c|c|c|c|c|}
\hline \multirow[b]{2}{*}{ Source } & \multirow[b]{2}{*}{$\begin{array}{l}\text { Area } \\
\text { Ratio }\end{array}$} & \multirow[b]{2}{*}{$\begin{array}{l}\text { Sediment load } \\
\qquad\left(\mathrm{kg} / \mathrm{m}^{2}\right)\end{array}$} & \multirow[b]{2}{*}{$\begin{array}{l}\text { Runoff load } \\
\text { (mm) }\end{array}$} & \multicolumn{6}{|c|}{ Removal (\%) } \\
\hline & & & & Sediment & Runoff & Nitrate $\mathrm{N}$ & Total N & Total P & Soluble P \\
\hline \multirow[t]{9}{*}{ (r) } & $2 \cdot 8$ & - & - & 98 & 84 & 85 & - & - & 0 \\
\hline & $4 \cdot 2$ & - & - & 99 & 97 & 97 & - & - & 46 \\
\hline & $8 \cdot 3$ & - & - & 100 & 99 & 100 & - & - & 83 \\
\hline & $2 \cdot 8$ & - & - & 87 & 43 & 47 & - & - & 42 \\
\hline & $4 \cdot 2$ & - & - & 100 & 54 & 69 & - & - & 22 \\
\hline & $8 \cdot 3$ & - & - & 100 & 94 & 99 & - & - & 89 \\
\hline & $2 \cdot 8$ & - & - & 91 & 87 & 86 & - & - & 79 \\
\hline & $4 \cdot 2$ & - & - & 97 & 93 & 95 & - & - & 89 \\
\hline & $8 \cdot 3$ & - & - & 98 & 85 & 97 & - & - & 89 \\
\hline \multirow[t]{8}{*}{ (s) } & $5 \cdot 4$ & $0 \cdot 8$ & 84 & 80 & 46 & 55 & 60 & 72 & 62 \\
\hline & $10 \cdot 8$ & 0.4 & 42 & 93 & 81 & 87 & 88 & 91 & 91 \\
\hline & $5 \cdot 4$ & $0 \cdot 8$ & 84 & 95 & 58 & 68 & 73 & 88 & 70 \\
\hline & $10 \cdot 8$ & 0.4 & 42 & 99 & 82 & 90 & 91 & 96 & 90 \\
\hline & 5.4 & $0 \cdot 8$ & 84 & 85 & 36 & 52 & 55 & 71 & 48 \\
\hline & $10 \cdot 8$ & 0.4 & 42 & 96 & 65 & 78 & 80 & 90 & 76 \\
\hline & $5 \cdot 4$ & $0 \cdot 8$ & 84 & 88 & 46 & 59 & 61 & 77 & 56 \\
\hline & $10 \cdot 8$ & 0.4 & 42 & 94 & 51 & 72 & 71 & 86 & 68 \\
\hline$(\mathrm{t})$ & $33 \cdot 0$ & - & - & 81 & 64 & & & & \\
\hline \multirow[t]{5}{*}{ (u) } & $44 \cdot 0$ & - & - & 85 & - & - & - & - & - \\
\hline & $22 \cdot 0$ & - & - & 90 & - & - & - & - & - \\
\hline & $11 \cdot 0$ & - & - & 90 & - & - & - & - & - \\
\hline & $7 \cdot 3$ & - & - & 90 & - & - & - & - & - \\
\hline & $5 \cdot 5$ & - & - & 96 & - & - & - & - & - \\
\hline \multirow[t]{24}{*}{ (v) } & $100 \cdot 0$ & 22.7 & 944 & 45 & -1 & - & - & - & - \\
\hline & $25 \cdot 0$ & 5.7 & 236 & 83 & 51 & - & - & - & - \\
\hline & $20 \cdot 0$ & $4 \cdot 2$ & 210 & 60 & -14 & - & - & - & - \\
\hline & $10 \cdot 0$ & $2 \cdot 1$ & 105 & 92 & 58 & - & - & - & - \\
\hline & $100 \cdot 0$ & $21 \cdot 5$ & 1076 & 54 & 1 & - & - & - & - \\
\hline & $25 \cdot 0$ & 5.4 & 269 & 74 & 15 & - & - & - & - \\
\hline & $20 \cdot 0$ & 1.6 & 180 & 64 & -4 & - & - & - & - \\
\hline & $10 \cdot 0$ & 0.8 & 90 & 96 & 72 & - & - & - & - \\
\hline & $20 \cdot 0$ & $2 \cdot 8$ & 195 & 77 & 8 & - & - & - & - \\
\hline & $10 \cdot 0$ & 1.4 & 98 & 100 & 95 & - & - & - & - \\
\hline & $20 \cdot 0$ & $3 \cdot 6$ & 214 & 82 & 33 & - & - & - & - \\
\hline & $10 \cdot 0$ & 1.8 & 107 & 92 & 50 & - & - & - & - \\
\hline & $20 \cdot 0$ & 1.7 & 190 & 52 & -22 & - & - & - & - \\
\hline & $10 \cdot 0$ & 0.9 & 95 & 98 & 76 & - & - & - & - \\
\hline & $10 \cdot 0$ & $1 \cdot 3$ & 197 & 84 & 28 & - & - & - & - \\
\hline & $20 \cdot 0$ & $2 \cdot 3$ & 203 & 94 & 64 & - & - & - & - \\
\hline & $10 \cdot 0$ & $1 \cdot 1$ & 101 & 99 & 90 & - & - & - & - \\
\hline & $100 \cdot 0$ & $20 \cdot 3$ & 1038 & 58 & 8 & - & - & - & - \\
\hline & $25 \cdot 0$ & $5 \cdot 1$ & 260 & 89 & 51 & - & - & - & - \\
\hline & $20 \cdot 0$ & $3 \cdot 3$ & 232 & 90 & 51 & - & - & - & - \\
\hline & $10 \cdot 0$ & 1.7 & 116 & 96 & 66 & - & - & - & - \\
\hline & $20 \cdot 0$ & $3 \cdot 6$ & 406 & 73 & 19 & - & - & - & - \\
\hline & $20 \cdot 0$ & $5 \cdot 8$ & 492 & 76 & 23 & - & - & - & - \\
\hline & $20 \cdot 0$ & $4 \cdot 8$ & 500 & 75 & 23 & - & - & - & - \\
\hline
\end{tabular}

Sources:

(a) (Abu-Zreig, et al., 2001); (b) (Arora, et al., 1996); (c) (Barfield, et al., 1998); (d) (Blanco-Canqui, et al., 2006); (e) (Chaubey, et al., 1994); (f) (Chaubey, et al., 1995) (g) (Coyne, et al., 1995); (h) (Coyne, et al., 1998); (i) (Daniels and Gilliam, 1996); (j) (Dillaha, et al., 1989); (k) (Lee, et al., 1998); (1) (Lee, et al., 2000) (m) (Lim, et al., 1998); (n) (Magette, et al., 1989); (o) (Mankin, et al., 2007); (p) (Munoz-Carpena, 1999); (q) (Parsons, et al., 1994); (r) (Patty, et al., 1997); (s) (Schmitt, et al., 1999); (t) (Sheridan, et al., 1999); (u) (Tingle, et al., 1998); (v) (Dijk, et al., 1996);

Notes:

$(\alpha)$ Data excluded due to large unexplained increase.

\section{Runoff reduction model}

No suitable runoff reduction model could be developed using the measured data derived from literature. Reported hydrologic soil group, rainfall rate and calculated runoff loading were able to explain $50 \%$ of the variability in 29 experiments which reported those data. Runoff loading was calculated as the total runoff volume from the upslope drainage area divided by the VFS area expressed as a depth (mm). Runoff loading combines several 
aspects of the source area hydrology and rainfall with $D A F S_{\text {ratio. Unfortunately, several studies did not report }}$ runoff reductions and/or soil series, severely limiting the data available for this analysis. The range in runoff loading present in these 29 experiments was insufficient to generate a model with applicability at higher flow concentrations. Only three of the 29 experiments had runoff loadings greater than $200 \mathrm{~mm}$ (equivalent to only $5 \mathrm{~mm}$ of runoff with a moderate $D A F S_{\text {ratio }}$ of 40). Due to this lack of data, the runoff reduction model was derived from the database of VFSMOD simulations.

VFSMOD parameter sensitivity. Prior to the development of a runoff reduction model, VFSMOD simulations were used to identify important factors in the retention of runoff and sediment in VFSs. Muñoz-Carpena et al. (1999) found initial soil water content and saturated hydraulic conductivity to be the most influential parameters on hydrology. Soil textural class was a sensitive parameter in our simulations. Saturated hydraulic conductivity was derived from soil textural class as described by Muñoz-Carpena and Parsons (2005), which may explain the sensitivity of soil texture. In our simulations, initial soil water content had little influence except under low intensity rainfall simulations.
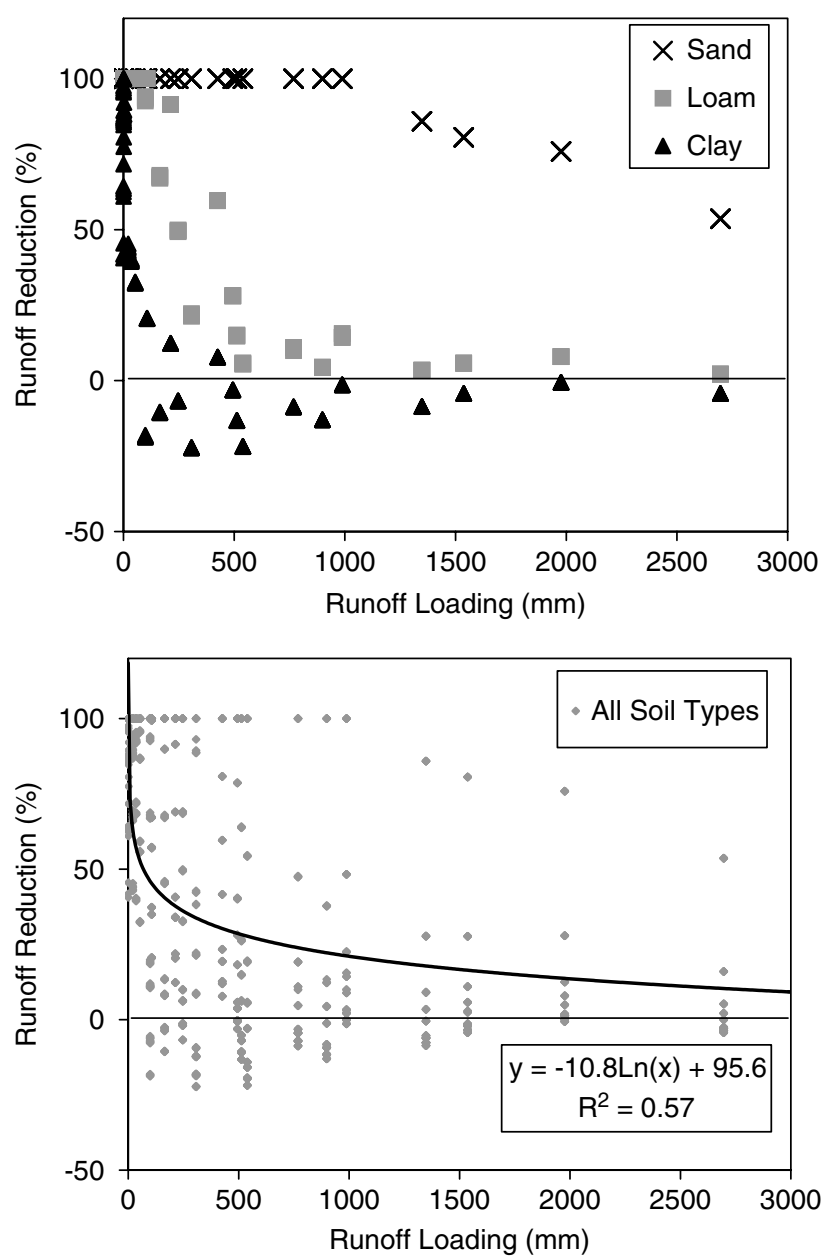

Figure 1. Runoff removal $(\%)$ as a function of runoff loading $(\mathrm{mm})$ for three soil types (top) and 11 soil types (bottom). Derived from Vegetative Filter Strip MODel (VFSMOD) simulations
Runoff loading was correlated with runoff reduction $\left(\mathrm{R}^{2}=0 \cdot 57\right)$ across all soil types (Figure 1$)$. The soil textural class had a significant effect on runoff reduction; soils with higher permeability (sands) were more effective. VFSs on soils with a high fraction of clay retained almost no runoff at moderate runoff loadings. In many cases, the rainfall alone was enough to saturate the infiltration ability of a VFS with a clay soil. Under these conditions, the VFS itself may become a source of runoff. Dillaha et al. (1989) reported increased runoff volume exiting a VFS in some experiments. These VFSs also became a source of soluble nitrogen and phosphorus.

Empirical model development. An empirical model for runoff reduction by VFSs was developed based on VFSMOD simulations. The model was derived from runoff loading and saturated hydraulic conductivity using the statistical package Minitab 15 (Minitab-Inc., 2006). Saturated hydraulic conductivity is available in SWAT, and runoff loading can be calculated from HRU-predicted runoff volume and $D A F S_{\text {ratio }}$. Both independent variables were transformed to improve the regression. The final form is given below:

$$
R_{R}=75.8-10 \cdot 8 \ln \left(R_{L}\right)+25.9 \ln \left(K_{S A T}\right)
$$

where $R_{R}$ is the runoff reduction $(\%) ; R_{L}$ is the runoff loading (mm); and $K_{S A T}$ is the saturated hydraulic conductivity $\left(\mathrm{mm} \mathrm{h}^{-1}\right)$. The regression was able to explain the majority of the variability $\left(\mathrm{R}^{2}=0.76 ; \mathrm{n}=1650\right)$ in the simulated runoff reduction. The resulting model (Figure 2) produced runoff reduction efficiencies from $-30 \%$ to $160 \%$. Reductions greater than $100 \%$ are not possible; these were an artefact of the regression model. VFSs in SWAT were not allowed to generate additional runoff or pollutants; the model was limited to a range of $0 \%$ to $100 \%$. The comparison between the empirical model and VFSMOD simulations improved $\left(\mathrm{R}^{2}=0.84\right)$ when the range was limited.

\section{Sediment reduction model}

The sediment reduction model developed for SWAT was based on measured VFS data. A VFS removes sediment by reducing runoff velocity due to increased resistance of the vegetative media and enhanced infiltration in the VFS area (Barfield et al., 1998). Both result in a reduction in transport capacity and the deposition of sediment. Both the filtering and infiltration aspects are represented in the model. Similar to the runoff loading approach used earlier, sediment loading per unit VFS area was found to correlate with measured sediment reduction. Dosskey et al. (2002) hypothesized that sediment trapping efficiency decreases as the load per unit of buffer area increases. Sediment loading was calculated as the mass of sediment originating from the upslope area per unit of VFS area express as $\mathrm{kg} \mathrm{m}^{-2}$. The infiltration aspect was represented in the model by incorporating the 

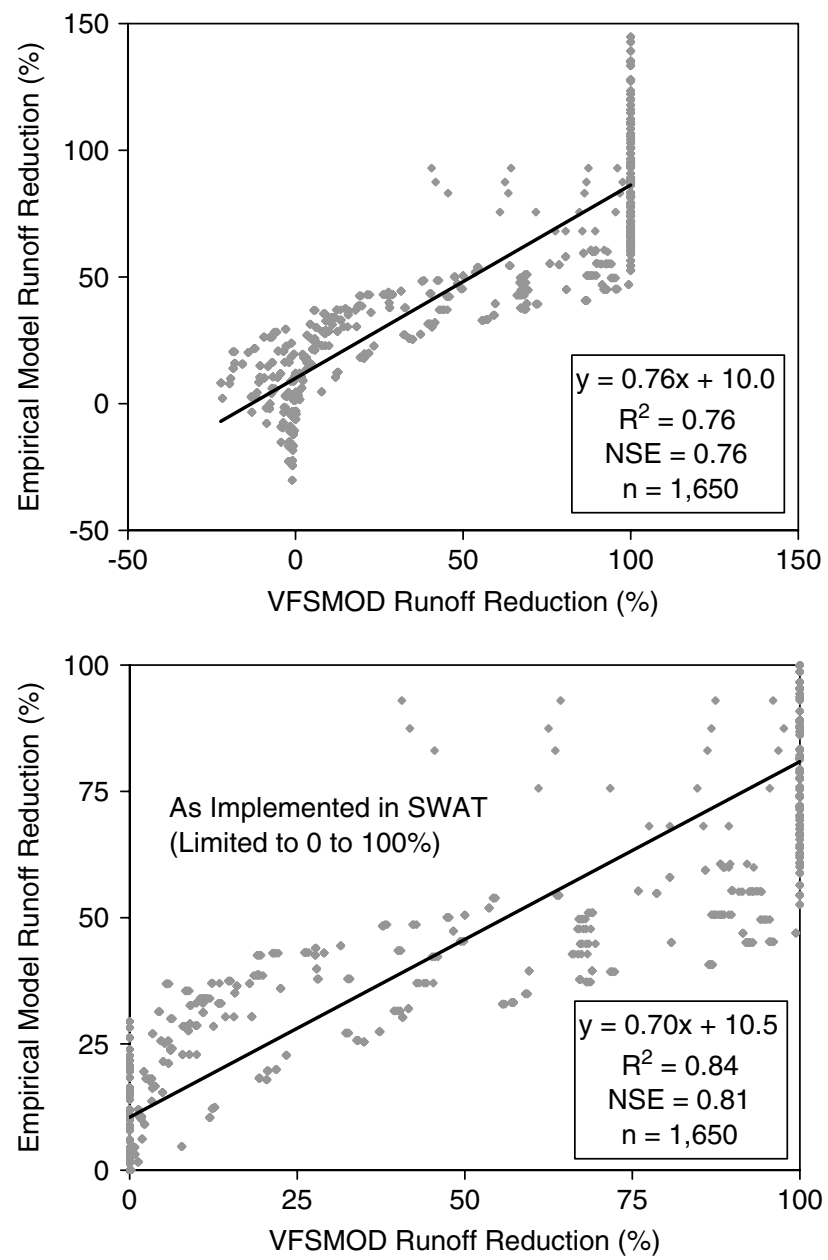

Figure 2. Empirical runoff reduction model compared with the VFSMOD dataset from which it is derived. As regressed (top) and limited from $0 \%$ to $100 \%$ (bottom). The limited form of the empirical model was implemented in SWAT. The Nash-Sutcliff Efficiency (NSE) and number of sample used in the regression (n) are also given

runoff reduction as a percentage. Sixty-two experiments reported in the literature were used to develop this model.

$$
S_{R}(\%)=79.0-1.04 S_{L}+0.213 R_{R}
$$

where $S_{R}$ is the predicted sediment reduction (\%); $S_{L}$ is sediment loading $\left(\mathrm{kg} / \mathrm{m}^{2}\right)$; and $R_{R}$ is the runoff reduction $(\%)$. Sediment loading alone was correlated with sediment reduction $\left(\mathrm{R}^{2}=0.41\right)$ (Figure 3$)$. The addition of runoff reduction allowed the regression model to explain most of the variability $\left(R^{2}=0.64\right)$ in the measured data.

\section{Nutrient reduction models}

In addition to the mechanisms by which sediment and runoff are captured, nutrients may be adsorbed onto vegetation, surface residues, or the soil surface (Barfield et al., 1998). For the sake of simplicity, nutrient reduction was considered to be a function of sediment or runoff reduction only. Only nitrogen and phosphorus were considered. All nutrient models were developed from measured VFS data; the current version of VFSMOD does not account for nutrients.
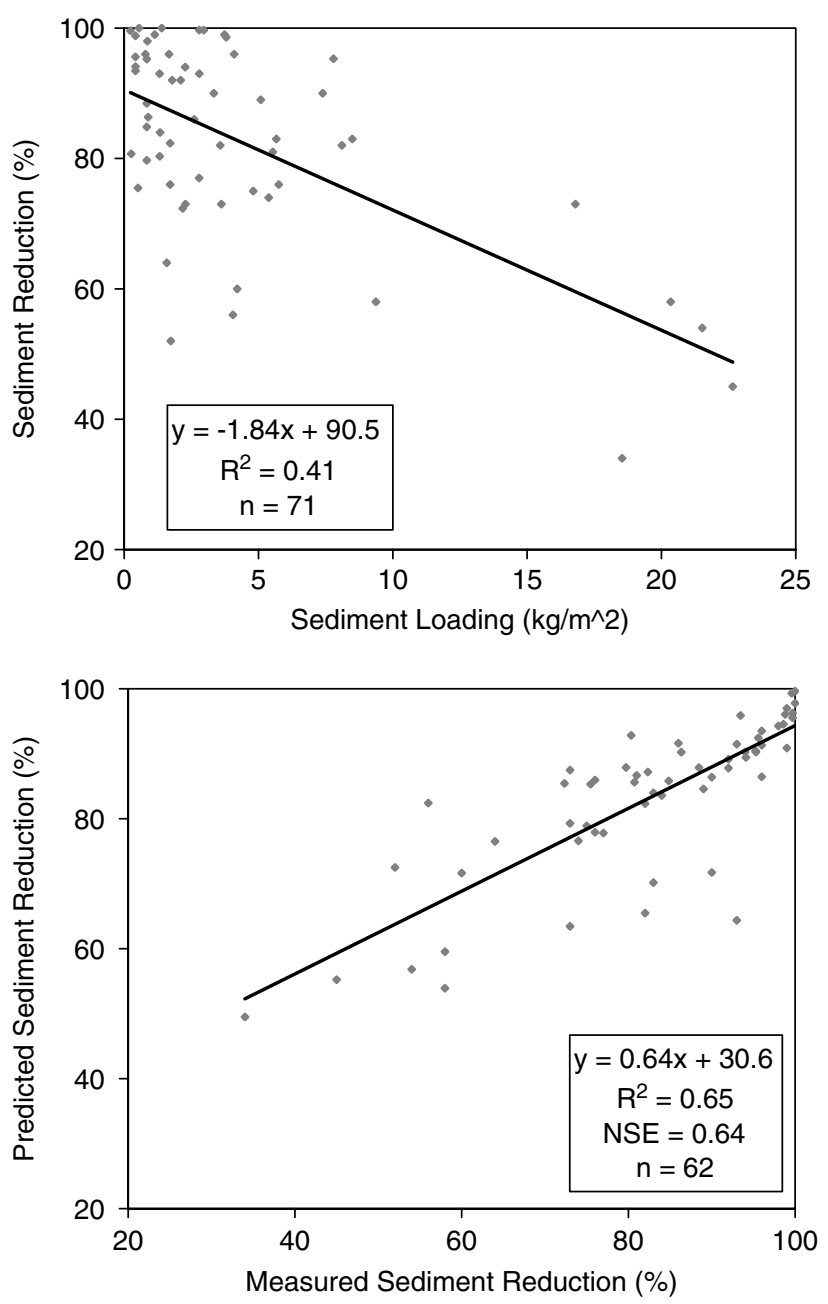

Figure 3. VFS sediment reduction as a function of sediment loading only (top). Final VFS sediment reduction model performance based on both sediment loading and runoff reduction (bottom). Both derived from measured data only

Total nitrogen. The total nitrogen model was based on sediment reduction only. Much of the nitrogen lost in runoff from agricultural fields travels with sediments. Harmel et al. (2006) found that approximately $75 \%$ of the nitrogen lost from conventional tilled fields was in particulate forms. They also found that dissolved nitrogen forms, such as nitrate, were more dominant in no-till treatments. The vast majority of VFS data derived from literature were designed to simulate higher erosion conditions where particulate forms would represent the majority of nitrogen losses.

The total nitrogen model was based on sediment reduction from 44 observations reported in the literature. Two trials were censored during the development of the model. These experiments from Magette et al. (1989) yielded significant increases in total nitrogen exiting the VFS. The authors attributed this phenomenon to flushing of fine particulates captured in the VFS from prior experimental trials. Both the slope and the intercept were significant $(P<0 \cdot 01)$. The model is given below and shown in Figure 4.

$$
T N_{R}=0.036 S_{R}^{1 \cdot 69}
$$



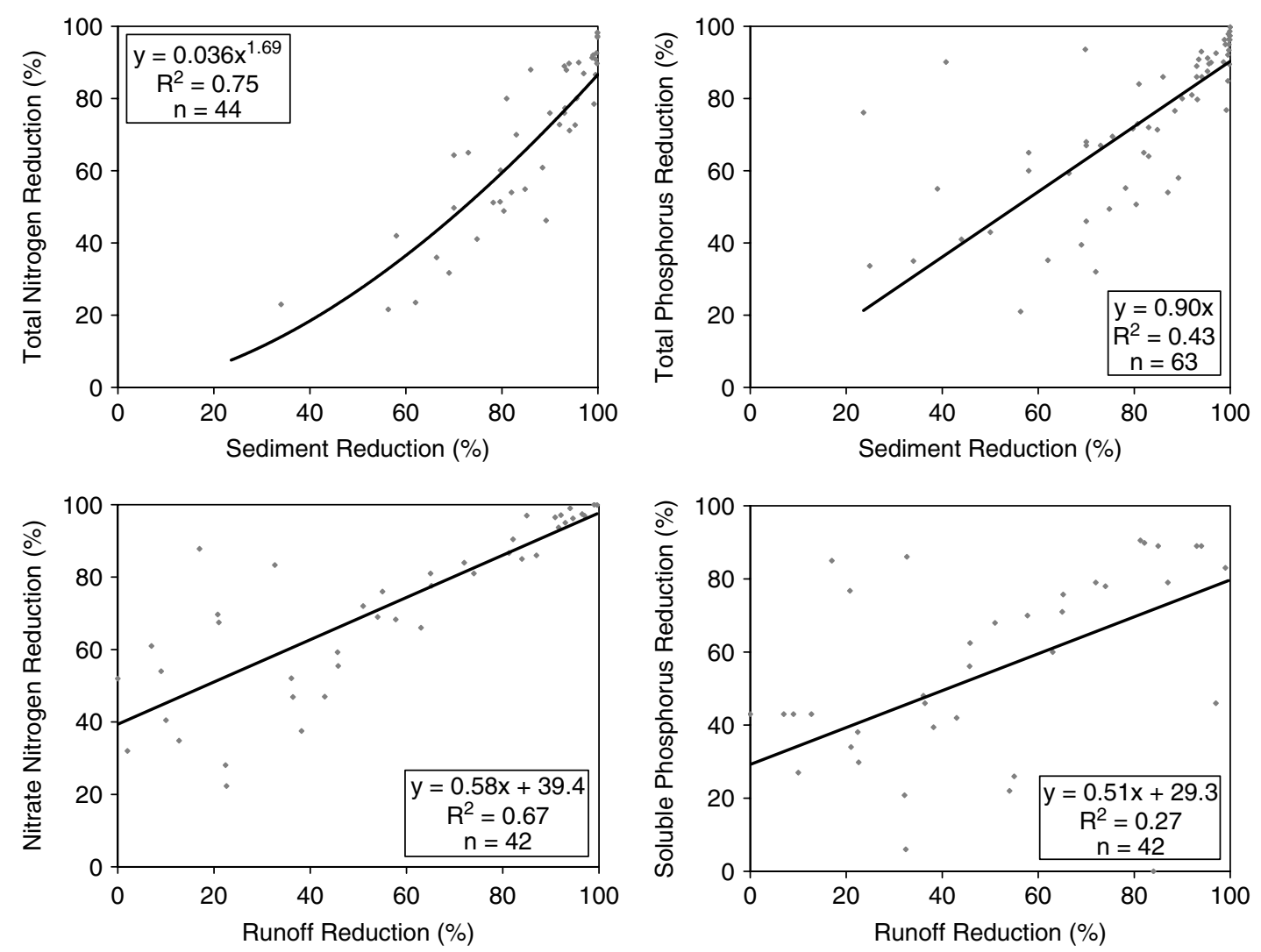

Figure 4. Nutrient reduction models for vegetative filter strip used in the SWAT vegetative filter strip submodel. Based on measured data reported in the literature

where $T N_{R}$ is the total nitrogen reduction (\%); and $S_{R}$ is the sediment reduction $(\%)$. Although this model was developed from total nitrogen, which includes both soluble and particulate forms, it was applied only to particulate forms in the SWAT model.

Nitrate nitrogen. The nitrate nitrogen model was developed from 42 observations. Four observations from Dillaha et al. (1989) had negative runoff reduction values due to additional runoff generated in the VFS. Because the VFS SWAT sub model is not allowed to generate additional loads, these observations were censored. All nutrient models initially included both runoff and sediment reductions as independent variables, but the nitrate nitrogen model was the only model where both were significant $(\alpha=0.05)$. Nitrate is soluble and should not be associated with sediments, yet they were statistically correlated in the measured data. It is likely that the relationship between nitrate and sediment is an artefact of cross- correlation between sediment and runoff reductions (as demonstrated by Equation (2)). The nitrate model was based only on runoff reduction; both the slope and the intercept were significant $(P<0 \cdot 01)$. The nitrate nitrogen model is given below:

$$
N N_{R}=39 \cdot 4+0 \cdot 584 R_{R}
$$

where $N N_{R}$ is the nitrate nitrogen reduction (\%); and $R_{R}$ is the runoff reduction (\%). Because both the slope and the intercept were significant, there is a minimum reduction of $39.4 \%$ in nitrate, even if there is no reduction in runoff due to the VFS. This outcome may be unexpected, but it is supported by the measured data. Dillaha et al. (1989) observed nitrate reductions of $52 \%$ and $32 \%$ with only $0 \%$ and $7 \%$ reductions in runoff volume. Lee et al. (2000) also found significant reductions in nitrate $(61 \%)$ with low runoff reductions (7\%). One possible explanation is that sufficient runoff can be generated in the VFS such that there is little net reduction in runoff, but significant infiltration may still occur. Another possibility is foliar uptake of nitrates by vegetation within the strip.

Total phosphorus. The model for total phosphorus was based on sediment reduction. Although total phosphorus is composed of both soluble and particulate forms, particulate forms represent the bulk of phosphorus lost from conventionally cultivated fields. The total phosphorus model was developed from 63 observations; more data than any other nutrient model. The intercept was not significant. Sediment reduction was able to explain $43 \%$ of the variability. The model was applied to all particulate forms of phosphorus in the SWAT VFS submodel. The model is given below:

$$
T P_{R}=0.90 S_{R}
$$

where $T P_{R}$ is the total phosphorus reduction (\%); and $S_{R}$ is the sediment reduction $(\%)$. 
Soluble phosphorus. The soluble phosphorus model was based on runoff reduction only. The observations censored from (Dillaha et al., 1989) for the nitrates were also censored for soluble phosphorus. The soluble phosphorus model has the weakest relationship of all the nutrient models $\left(\mathrm{R}^{2}=0 \cdot 27\right)$, yet both the slope and intercept were significant $(P=0 \cdot 01)$.

$$
D P_{R}=29 \cdot 3+0.51 R_{R}
$$

where $D P_{R}$ is the dissolved phosphorus reduction (\%); and $R_{R}$ is the runoff reduction (\%). Like nitrate, there is a significant reduction in soluble phosphorus $(29.3 \%)$ with no corresponding runoff reduction. Experimental observations of soluble phosphorus reduction at low runoff reductions are highly variable. Dillaha et al. (1998) found reductions in soluble phosphorus ranging from $43 \%$ to $-31 \%$ with near zero runoff reduction. The minimum reduction predicted by Equation (6) could be the result of mechanisms similar to those cited for the removal of nitrates, or simply an artifact of experimental variability.

\section{ADAPTATION TO THE FIELD SCALE}

On-farm VFSs are likely significantly less effective than their plot scale counterparts (Dillaha et al., 1989; Helmers, 2003; Gert et al., 2006). Plot scale assessments generally relied upon to evaluate the effectiveness of VFSs are usually conducted under uniform sheet flow conditions. Even under plot scale conditions uniform sheet flow can be difficult to maintain. Abu-Zreig et al. (2001) found unintended concentrated flow in the majority of their plot scale experiments, some with flow restricted to less than half of the available plot width. Only a few plot scale studies have addressed concentrated flow (Dillaha et al., 1989; Blanco-Canqui et al., 2006). Blanco-Canqui et al. (2006) evaluated VFSs under interrill and concentrated flow and found removal reduced by $10 \%$ to $25 \%$ under concentrated flow conditions. Dillaha et al. (1989) included plots with a 4\% cross-slope to encourage concentrated flow. The concentrated plots received lower runoff and sediment loadings than the uniform flow plots, possibly masking the effects of flow concentrations in their results.

Little research exists to address the effectiveness of this important conservation practice at the field scale. A few researchers have investigated converging and divergent flows at the field scale for evaluating the effectiveness of VFSs or riparian buffers (Dosskey et al., 2002; Helmers et al., 2005; Kim et al., 2006). Kim et al. (2006) evaluated the movement of phosphorus within a buffer receiving milkhouse waste. Despite the use of a level lip spreader, concentrated flow paths occurred. Helmers et al. (2005) used high resolution topographical data to evaluate flow convergence and its effects on VFS efficiency at the field scale. They identified areas of flow convergence and divergence, but VFS effectiveness for both areas was about the same.
The amount of convergence on their study site was less than that measured on other sites, possibly due to grading for surface irrigation prior to monitoring. Dosskey et al. (2002) used VFSMOD to evaluate the performance of riparian buffers on four fields. They found significant reductions in performance due to non-uniform flows.

Even fewer studies address the effectiveness of VFSs at the watershed scale. Gert et al. (2006) used the spatially distributed soil erosion and sediment delivery model (WATEM/SEDEM) (Oost et al., 2000) to evaluate VFSs at various spatial scales. They found flow convergence to be increasingly important at larger spatial scales. At the plot scale the model predicted $70 \%$ efficiency; at the watershed scale, efficiency dropped to just $20 \%$. It seems clear that on a typical field, a VFS should be significantly less effective than plot studies indicate.

\section{Assessing concentrated flow}

To evaluate the effectiveness of VFSs at the field scale, some assessment of flow uniformity across the field and through a VFS is needed. One method to predict runoff movement over a surface is flow accumulation. Flow accumulation is a widely used technique to predict watershed boundaries and stream networks at the watershed scale (Jenson and Domingue, 1988; Quinn et al., 1991). Available topographic information in the form of digital elevation models (DEMs) can be used within a geographic information system (GIS) to predict how runoff, generated uniformly over a surface, moves down slope through the raster from cell to cell. The flow accumulation value assigned to each cell is equivalent to its drainage area. DEMs with a resolution of $30 \mathrm{~m}$ are widely available and adequate for watershed scale assessments. Recent advancements in airborne light detection and ranging (LiDAR) have made high resolution DEM generation more cost effective (Xiaoye 2008). LiDAR data are returned as a cloud of three- dimensional coordinates which are filtered to remove surface vegetation and interpolated into a high resolution DEM. The resolution of these DEMs makes the assessment of flow at the hillslope or field scale possible.

A multiple flow algorithm (Quinn et al., 1991; Schäuble, 2003) was used to define flow accumulation. In a traditional single flow accumulation, each cell in the raster passes all of its accumulated flow to its most down slope neighbour. The multiple flow approach sends flow to all downslope neighbours; the division of flow is based on relative differences in slope among the cells. A comparison of single path and multipath flow accumulation products and techniques is given in Figure 5. Single path flow accumulations are angular and unrealistic at smaller spatial scales. Multiple path flow results in a much smoother more realistic assessment of flow.

\section{Study sites}

Study sites were selected to evaluate the distribution of flow through hypothetical VFSs in the USA. Ten 

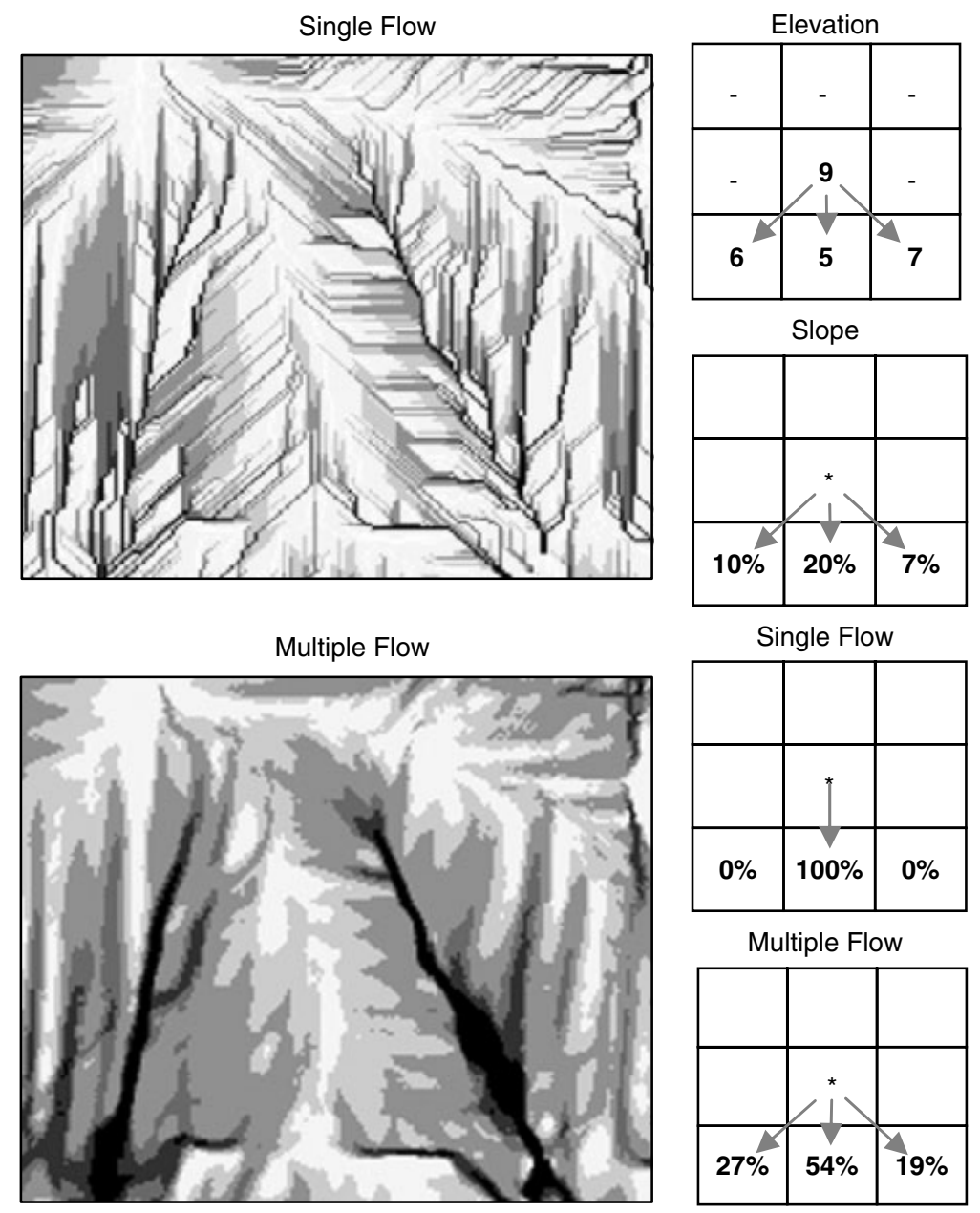

Figure 5. Comparison of single path and multiple path flow accumulation. Example calculation shown on the right, finished product shown on left. Slope is derived from the elevation grid. Single flow routes all flow to most downslope cell; multiple flow distributes flow to all downslope cells based on relative differences in slope

cultivated agricultural fields were selected from aerial photography as candidates for VFSs, four in Ada County, ID and six in Shawnee County, KS. Both counties have publicly available LiDAR bare earth DEMs with a resolution of $2 \mathrm{~m}$. All study sites had a slope less than $3.6 \%$. Unfortunately, all steeper cultivated fields with LiDAR coverage in these counties were terraced.

\section{Flow accumulation processing}

Bare earth DEMs generated from LiDAR data were filtered using a circular mean filter with a radius of $6 \mathrm{~m}$ in ArcGIS for all study sites. This was necessary to prevent random errors in the DEM from directing surface flow in fields with little slope. These errors may arise during the separation of bare earth and crop canopy LiDAR returns. The separation of bare earth returns is among the most critical and difficult processes in DEM generation (Xiaoye, 2008). The DEMs were processed to remove sinks using ArcGIS 9.2 to prevent erroneous flow accumulation values. A sink is a cell or group of cells with an elevation lower than that of all surrounding cells; they do not discharge the flow they accumulate. Because the flow accumulation algorithm does not consider the ponded depth of runoff, even sinks a few $\mathrm{mm}$ in depth must be filled. Sinks may be real or artefacts of DEM generation; large sinks in the study areas were attributable to DEM errors upon visual inspection of aerial photography. Vegetated fencerows and tramlines were associated with some sinks. Smaller sinks could be associated with DEM errors or natural soil depressions, regardless of their origin all sinks were filled. A multipath flow accumulation routine was applied to each of the ten study fields in ArcView 3.2. The extension Hydrotools 1.0 (Schäuble, 2003) was applied to the filtered sinkless DEMs to generate a multiple path flow accumulation for each field.

\section{VFS flow distributions}

Hypothetical VFSs were delineated at the edge of each study field in the GIS. Flow accumulation in cells designated as VFSs were used to evaluate how much field runoff would be treated by each portion of the VFS. An example is given in Figure 6. In this field, a hypothetical $3 \mathrm{~m}$ wide VFS received runoff from a 6.7 ha

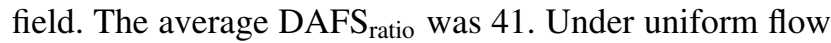
conditions, each square meter of VFS would treat runoff from $41 \mathrm{~m}^{2}$ of cultivated area. The flow accumulation found that $30 \%$ of the buffer received only $5 \%$ of the 

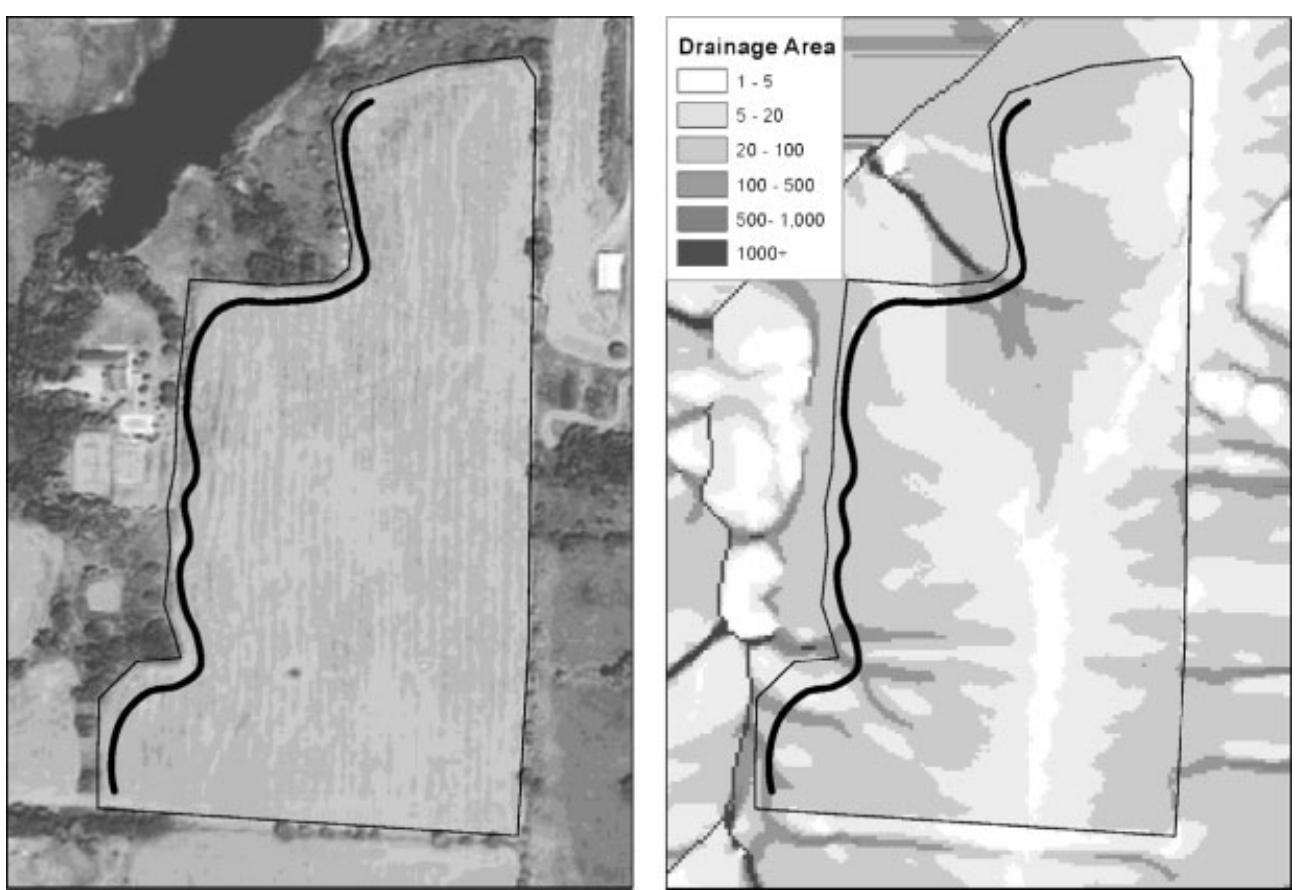

Figure 6. Example 6.7 ha study site with a hypothetical $3 \mathrm{~m}$ wide vegetative filter strip (drainage/VFS area ratio $=41)($ corrected for actual drainage are to the strip). Flow accumulation along entire filter strip used in flow distribution predictions

field runoff $\left(\mathrm{DAFS}_{\text {ratio }}=6 \cdot 8\right)$. The $10 \%$ of the VFS with the most concentrated flow received $40 \%$ of the flow from the entire field $\left(\mathrm{DAFS}_{\text {ratio }}=164\right)$. This example demonstrates the non-uniformities present at the field scale.

Figure 7 describes the nonuniformities by comparing the cumulative fraction of VFS area with the cumulative fraction of total drainage area for each of the ten study sites. A VFS receiving uniform flow would be represented by the $1: 1$ line, the more convex the curvature the more non-uniform the flow. We found that $10 \%$ of the VFS area received between $25 \%$ and $75 \%$ of the total field runoff. On average about $50 \%$ of the runoff passed through $10 \%$ of the VFS. This fraction of runoff received by the worst $10 \%$ of the VFS was used to develop a simplified model describing the flow distribution in the VFS (Figure 7). This simple approach was favoured over more complex multi-parameter distribution models because it is described by a single physically meaningful parameter. Studies of flow non-uniformity in VFSs and riparian buffers bracket these findings. Dosskey et al. (2002) found that $6 \%$ to $50 \%$ of the total riparian buffer area was used to effectively treat field runoff. Dosskey et al. (2002) found on average a greater degree of nonuniformity than expressed at our ten study sites. However VFSs and riparian buffers may not be directly comparable due to differing geomorphic and tillage history. Helmers et al. (2005) found convergence ratios between -1.55 and 0.34 within a single VFS, equivalent to different sections receiving from $40 \%$ to $150 \%$ of the average flow. All ten study sites exhibited more non-uniform flow than Helmers et al. (2005), possibly attributable to grading of their study field for surface irrigation prior to monitoring.
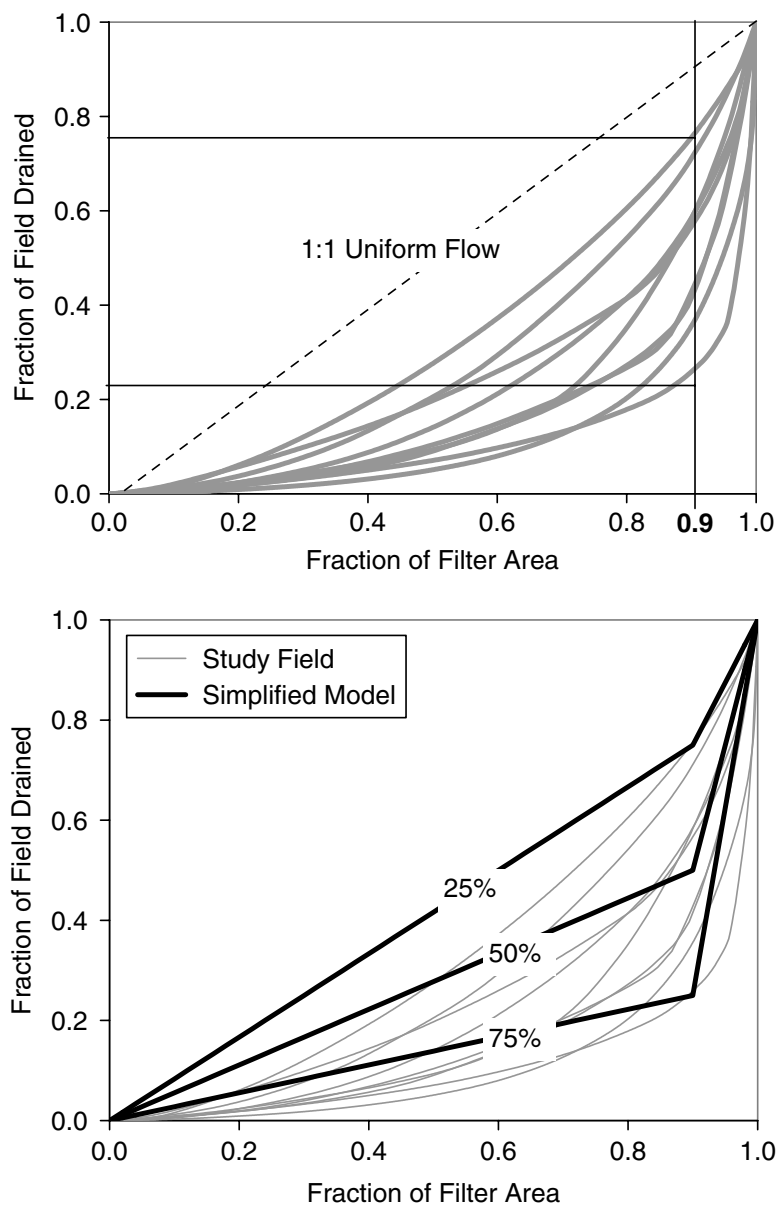

Figure 7. Flow uniformity in ten hypothetical vegetative filter strips based on multiple path flow accumulation. Greater convex curvature indicates greater flow non-uniformity. Between $25 \%$ and $75 \%$ of the flow passed though just $10 \%$ of the filter strip area (top). Simplified linear model of flow distribution based on the drainage area of the most concentrated $10 \%$ of the filter area (bottom) 


\section{VFS SWAT MODEL STRUCTURE}

VFSs were implemented at the HRU level in SWAT. Three additional model parameters were added as SWAT inputs: the drainage area to VFS area ratio $\left(D A F S_{\text {ratio }}\right)$, the fraction of the field drained by the most heavily loaded $10 \%$ of the VFS $\left(D F_{c o n}\right)$, and the fraction of the flow through the most heavily loaded $10 \%$ of the VFS which is fully channelized $\left(C F_{\text {frac }}\right)$, all are specified in the HRU (.hru) file. A two-segment VFS was used. Section one represents the bulk of the VFS area $(90 \%)$ which receives the least flow. Section two is the remaining $10 \%$ of the buffer which receives between $25 \%$ and $75 \%$ of the field runoff (Figure 8). The fraction of flow through section two which is channelized is not subject to the VFS model; all sediment and nutrient are conservatively delivered to the tributary channel. $D A F S_{\text {ratio }}$ for sections one and two are calculated from $D F_{\text {con }}$ using the following equations:

$$
\begin{aligned}
& D A F S_{\text {ratio } 1}=D A F S_{\text {ratio }}\left(1-D F_{\text {con }}\right) / 0 \cdot 9 \\
& D A F S_{\text {ratio } 2}=D A F S_{\text {ratio }}\left(1-C F_{\text {rac }}\right) D F_{\text {con }} / 0 \cdot 1
\end{aligned}
$$

where $D A F S_{\text {ratiol } 1}$ is the drainage area to VFS area ratio for section $1 ; D A F S_{\text {ratio } 2}$ is the drainage area to the VFS area ratio for section $2 ; D A F S_{\text {ratio }}$ is the average drainage area to the VFS area ratio for the entire HRU (user input); $C F_{\text {frac }}$ is fraction of the flow through the most heavily loaded $10 \%$ of the VFS which is fully channelized (user input); and $D F_{c o n}$ is the fraction of the field drained by the most heavily loaded $10 \%$ of the VFS (user input). Sediment, runoff, and nutrient loadings are calculated assuming all are generated uniformly across the HRU. The DAF $S_{\text {ratio }}$ for each VFS section is combined with SWAT HRUlevel runoff and sediment yield predictions to calculate the runoff and sediment loadings. Equations (1)-(6) are applied to predict sediment and nutrient transport through

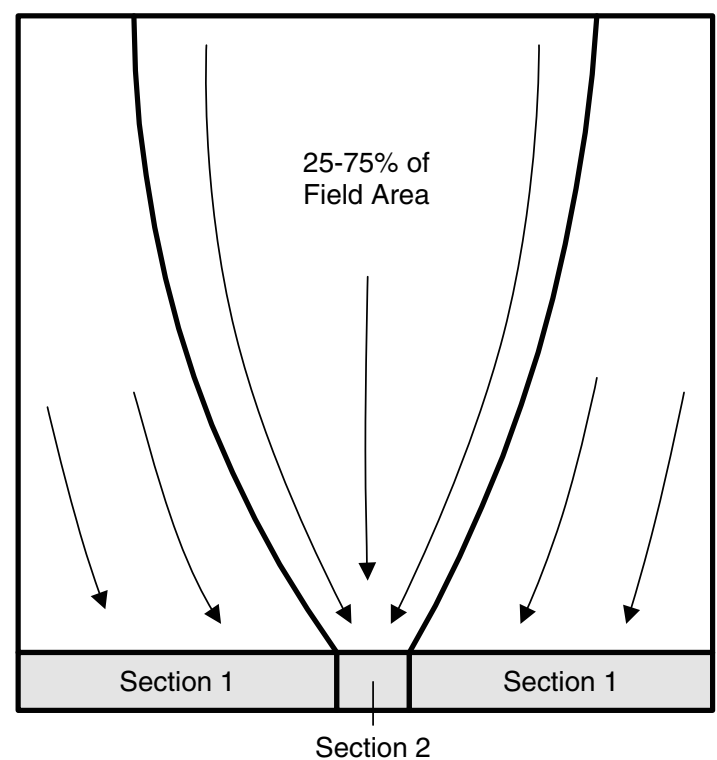

Figure 8. Graphical representation of HRU drainage and two-section vegetative filter strip as implemented in SWAT the VFS. The fraction of runoff retained in VFS is calculated for the purposes of estimating the retention of other constituents only. It is beyond the scope of this research to predict the aspects of a VFS's hydrologic budget needed to represent that component in the SWAT model. In addition, the area occupied by VFSs within a SWAT HRU is not removed from that HRU for simplicity. For these reasons, the VFS routine in SWAT is not used to predict changes in runoff delivered to streams.

The VFS SWAT submodel also includes pesticides and bacteria. Due to a lack of measured data, these models are based on assumptions. The pesticide model assumes that pesticides sorbed to sediments are captured with the sediment, and soluble pesticides are captured with runoff. Similarly, bacteria, which are attached to sediment, are captured with sediment and unattached bacteria are captured with runoff. These assumptions are common in the structure of other SWAT model components.

\section{MODEL VERIFICATION AND SENSITIVITY}

Several simulations were preformed to verify that the VFS SWAT submodel was functional. A 50 year simula-
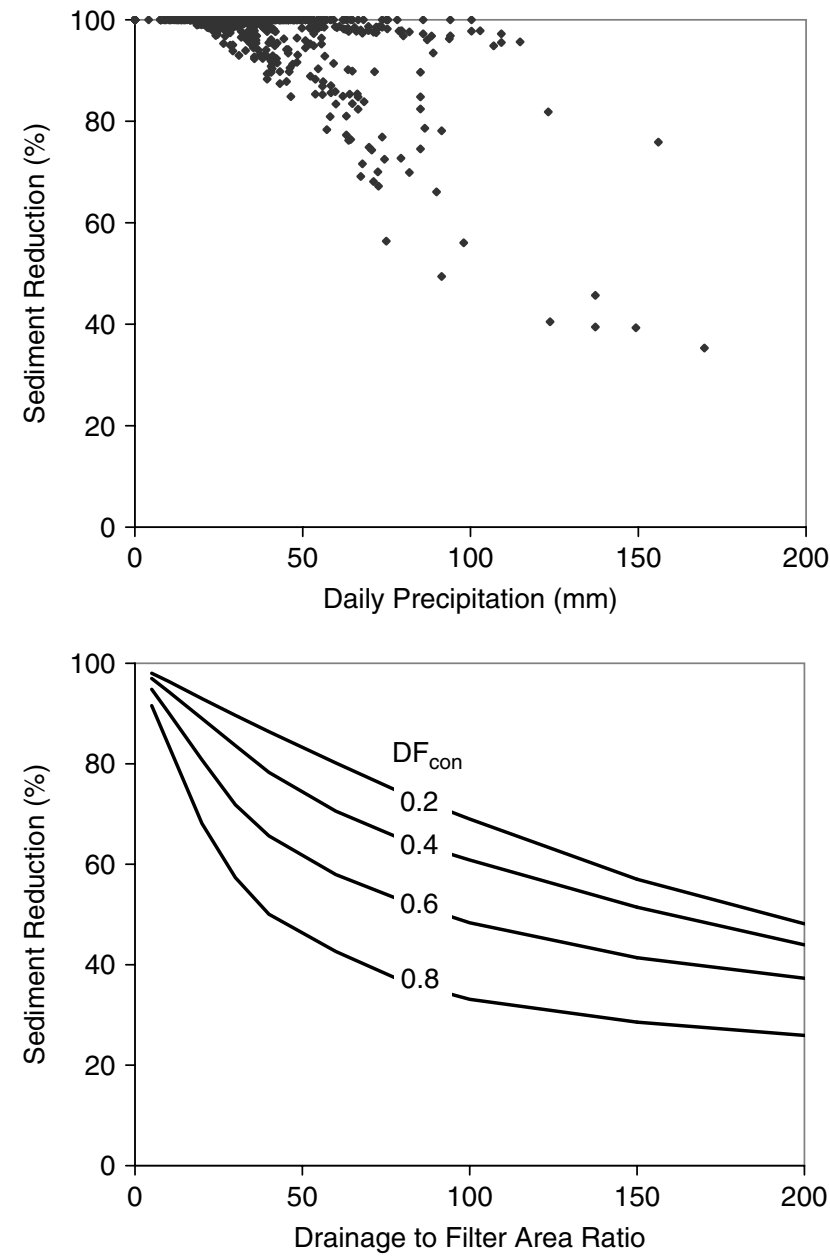

Figure 9. Sediment reduction in a vegetative filter strip as a function of rainfall intensity (top) and drainage to filter area ratio $\left(D A F S_{\text {ratio }}\right)$ and fraction of the field drained by the most heavily load $10 \%$ of the filter strip $\left(D F_{c o n}\right)$ (bottom). Derived from SWAT simulations 
tion of winter wheat on a Tipton loam soil with a $D A F S_{\text {ratio }}$ of 40 , a $D F_{\text {con }}$ of 0.5 and a $C F_{\text {frac }}$ of 0 , was performed. These three user inputs are required to simulate VFSs in SWAT. The field averaged 3.7 $\mathrm{Mg} \mathrm{ha}^{-1}$ of soil loss over the period. The VFS removed on average $73 \%$ of the sediment from the runoff. The effectiveness of the VFS was highly dependent upon the magnitude of the daily rainfall. Figure 9 depicts the relationship between daily rainfall and sediment reduction due to the VFS in this simulation. Sediment resulting from small precipitation events were nearly completely contained. Efficiency was dramatically reduced during larger events. Plot scale studies are often conducted with very high rainfall intensities. The use of extreme rainfall intensities may partially compensate for the lack of concentrated flow in extrapolations from plot to field scale. Figure 9 appears to contain a bimodal relationship, possibly due to the mixing of data from the growing season and the summer fallow when sediment transport is higher due to poor surface cover.

To evaluate the effect of $D A F S_{\text {ratio }}$ and $D F_{\text {con }}$ on VFS effectiveness, a series of SWAT simulations was performed. $C F_{\text {frac }}$ was excluded from this analysis because it is a simple bypass function for sediment and nutrients, useful only when a portion of the VFS has failed. 4800 simulations of conventionally tilled wheat with $D A F S_{\text {ratio }}$ values from 5 to 200 and $D F_{\text {con }}$ values from 0.2 to 0.8 were explored in combination with 86 randomly selected soils. Soil type had a large effect of on sediment removal by VFSs. With $D A F S_{\text {ratio }}$ fixed at 40 and a $D F_{c o n}$ set to 0.5 sediment reductions ranged from $51 \%$ to $89 \%$ across the 86 soils. To better visualize the effects $D A F S_{\text {ratio }}$ and $D F_{\text {con }}$, a single soil (Tipton loam) was extracted from the simulations and is shown in Figures 9 and 10. All results fit the general trend of reduced effectiveness at higher values of $D A F S_{\text {ratio }}$ and $D F_{c o n}$. The filter strip model, like any model, is not applicable in every situation. The range of $D A F S_{\text {ratio }}$ and $D F_{c o n}$ values explored in the sensitivity analysis were consistent with those in the data from which the models were developed.

\section{DISCUSSION AND CONCLUSIONS}

The VFS SWAT submodel presented here was based on a great deal of measured data collected by researchers in several countries. The data were collected using differing experimental protocols, soils, slopes and rainfall intensities. Many experiments were conducted without replication, further adding to the variability. Despite the inconstancies between experimental trials, meaningful models were derived from these data. When measured data was lacking, predictions from the process-based VFSMOD model were used. The runoff model developed from VFSMOD simulations, despite the high coefficient of determination, contains an additional level of uncertainty from VFSMOD. In the absence of sufficient measured
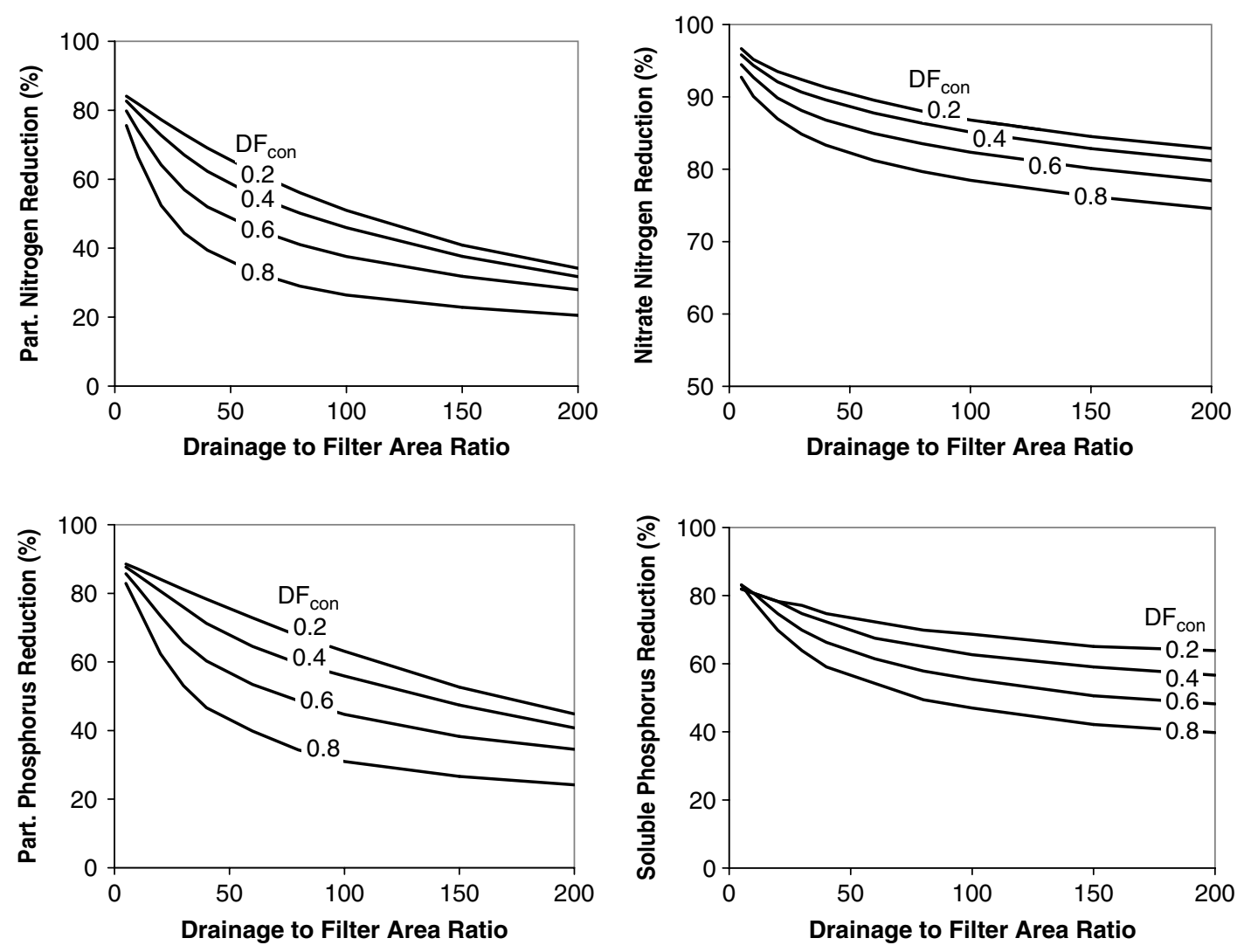

Figure 10. Effect of drainage to filter area ratio $\left(D A F S_{\text {ratio }}\right)$ and fraction of the field drained by the most heavily load $10 \%$ of the filter strip $\left(D F_{\text {con }}\right)$ on nutrient reduction in filter strips. Derived from SWAT simulations of wheat on a Tipton loam soil 
data to fully characterize the runoff processes occurring within a VFS, these simulations filled a gap in our understanding.

No validation of the VFS SWAT submodel was performed. No suitable field scale data for this task was available. It would be extremely difficult to measure VFS performance at the field scale especially for the duration needed to evaluate a model; it is unlikely that these data will ever be plentiful. Even plot scale data collected under natural rainfall are scarce. In lieu of model validation, a model verification and sensitivity analysis was performed to evaluate how each model input effects sediment and nutrient retention. The model presented here has a solid basis in measured data and theoretical adaptation for non-uniform flow.

Scaling the effectiveness of VFSs from the plot to the field scale is difficult and highly dependent upon local conditions, which are difficult to assess. We have provided a reasonable range for the parameters that define the VFS submodel to allow its use at the watershed scale. The applicability of the model is limited to the range of conditions represented by the data used to develop it. Most of the measured data used to develop the model was designed to represent cultivated fields, in which particulate nutrient losses dominate. The applicability of this model to other conditions such as no-till or pasture contains additional uncertainty. It is likely that there is a relationship between slope and concentrated flow but no significant relationship was found among the ten sites used in this study, possibly due to all study sites having slopes less than $3.6 \%$. A broader set of study fields including steeper areas could allow development of a generalized relationship between slope and $D F_{\text {con }}$, making watershed scale assessments more accurate.

Many researchers suggest that plot scale studies overestimate the real effectiveness of VFSs. This is likely true due to the overwhelming effects of flow concentration, but the use of extreme rainfall events in plot studies should partially counteract this effect at the field scale. Most plot scale studies included a single large simulated rainfall event and do not characterize the response of VFSs to far more common smaller events. We found that VFSs are more effective during these smaller events. In this way, most plot scale studies may underestimate the average retention of sediment and nutrients under natural rainfall. The amount of concentrated flow differs tremendously with local conditions making it difficult to speculate on how plot experiments and real VFSs compare.

A model by definition is a simplification of the real world. All models have limitations because the science behind them is neither perfect nor complete. Despite its potential limitations the VFS submodel is useful, and should enhance the ability of SWAT to evaluate the effectiveness of a very common conservation measure at the watershed scale.

\section{REFERENCES}

Abu-Zreig M, Rudra RP, Whiteley HR. 2001. Validation of a vegetated filter strip model (VFSMOD). Hydrological Processes 15(5): 729-742. Arabi M, Frankenberger JR, Engel BE, Arnold JG. 2008. Representation of agricultural conservation practices with SWAT. Hydrological Processes 22(16): 3042-3055.

Arnold JG, Srinivasan R, Muttiah RS, Williams JR. 1998. Large area hydrologic model development and assessment Part 1: Model development. Journal of the American Water Resources Association 34(1): 73-89.

Arora K, Mickelson S, Baker J, Tierney D, Peters C. 1996. Herbicide retention by vegetative buffer strips from runoff under natural rainfall. Transactions of the ASAE 39(6): 2155-2162.

Barfield BJ, Blevins RL, Fogle AW, Madison CE, Inamdar S, Carey DI, Evangelou VP. 1998. Water quality impacts of natural filter strips in karst areas. Transactions of the ASAE 41(2): 371-381.

Blanco-Canqui H, Gantzer CJ, Anderson SH. 2006. Performance of grass barriers and filter strips under interrill and concentrated flow. Journal of Environmental Quality 35(6): 1969-1974.

Bracmort KS, Arabi M, Frankenberger JR, Engel BA, Arnold JG. 2006. Modeling long-term water quality impact of structural BMPs. Transactions of the ASABE 49(2): 367-374.

Chaubey I, Edwards DR, Daniel TC, Moore PA, Nichols DJ. 1994. Effectiveness of vegetative filter strips in retaining surface-applied swine manure constituents. Transactions of the ASABE 37: 845-850.

Chaubey I, Edwards DR, Daniel TC, Moore PA, Nichols DJ. 1995. Effectiveness of vegetative filter strips in controlling losses of surfaceapplied poultry litter. Transactions of the ASABE 38(6): 1687-1692.

Chu T, Shirmohammadi A, Abbott L, Sadeghi A, Montas H. 2005. Watershed level BMP evaluation with SWAT model. In Proceedings of the American Society of Agricultural Engineers Annual International Meeting, July 17-20, 2005, Tampa, Florida, USA. ASABE Publication number 052098 .

Coyne MS, Gilfillen RA, Rhodes RW, Blevins RL. 1995. Soil and fecal coliform trapping by grass filter strips during simulated rain. Journal of Soil and Water Conservation 50(4): 405-408.

Coyne MS, Gilfillen RA, Rhodes R, Villalba A, Zhang Z, Dunn L, Blevins RL. 1998. Fecal bacteria trapping by grass filter strips during simulated rain. Journal of Soil and Water Conservation 53(2): $140-145$.

Daniels RB, Gilliam JW. 1996. Sediment and chemical load reduction by grass and riparian filters. Soil Science Society of America Journal 60(1): 246-251.

Dijk PMV, Kwaad FJPM, Klapwijk M. 1996. Retention of water and sediment by grass strips. Hydrological Processes 10(8): 1069-1080.

Dillaha TA, Reneau RB, Mostaghimi S, Lee D. 1989. Vegetative filter strips for agricultural nonpoint source pollution control. Transactions of the ASAE 32(2): 513-519.

Dorioz JM, Wang D, Poulenard J, Trévisan D. 2006. The effect of grass buffer strips on phosphorus dynamics-a critical review and synthesis as a basis for application in agricultural landscapes in France. Agriculture, Ecosystems \& Environment 117(1): 4-21.

Dosskey MG, Helmers MJ, Eisenhauer DE, Franti TG, Hoagland KD. 2002. Assessment of concentrated flow through riparian buffers. Journal of Soil and Water Conservation 57(6): 336-343.

Gassman PW, Reyes MR, Green CH, Arnold JG. 2007. The soil and water assessment tool: Historical development, applications and future research directions. Transactions of the ASABE 50(4): 1211-1250.

Gert V, Jean P, Katleen G, Gerard G. 2006. The use of riparian vegetated filter strips to reduce river sediment loads: an overestimated control measure? Hydrological Processes 20(20): 4259-4267.

Goel PK, Rudra RP, Gharabaghi B, Das S and Gupta N. 2004. Pollutants removal by vegetative filter strips planted with different grasses. 2004 ASAE/CSAE Annual International Meeting, August 1-4, 2004, Ottawa, Ontario, Canada. ASAE Publication number 042177.

Harmel D, Potter S, Ellis P, Reckhow K, Green C. 2006. Compilation of measured nutrient load data for agricultural land uses in the United States. Journal of the American Water Resources Association 42(5): $1163-1178$.

Helmers MJ. 2003. Two-dimensional overland flow and sediment trapping in a vegetative filter. $\mathrm{PhD}$ dissertation, University of Nebraska, Lincoln, NE USA.

Helmers MJ, Eisenhauer DE, Dosskey MG, Franti TG, Brothers JM, McCullough MC. 2005. Flow pathways and sediment trapping in a field-scale vegetative filter. Transactions of the ASAE 48(3): 955-968.

Jenson SK, Domingue JO. 1988. Extracting topographic structure from digital elevation data for geographic information system 
analysis. Photogrammetric Engineering and Remote Sensing 54(11): $1593-1600$.

Kim YJ, Geohring LD, Jeon JH, Collick AS. 2006. Evaluation of the effectiveness of vegetative filter strips for phosphorus removal with the use of a tracer. Journal of Soil and Water Conservation 61(5): 293-302.

Koelsch RK, Lorimor JC, Mankin KR. 2006. Vegetative treatment systems for. management of open lot runoff: review of literature. Applied Engineering in Agriculture 22(1): 141-153.

Krutz LJ, Senseman SA, Zablotowicz RM, Matocha MA. 2005. Reducing herbicide runoff from agricultural fields with vegetative filter strips: a review. Weed Science 53(3): 353-367.

Lee KH, Isenhart TM, Schultz RC, Mickelson SK. 1998. Nutrient and sediment removal by switchgrass and cool-season grass filter strips in Central Iowa, USA. Agroforestry Systems 44(2-3): 121-132.

Lee KH, Isenhart TM, Schultz RC, Mickelson SK. 2000. Multispecies riparian buffers trap sediment and nutrients during rainfall simulations. Journal of Environmental Quality 29(4): 1200-1205.

Lim TT, Edwards DR, Workman SR, Larson BT, Dunn L. 1998. Vegetated filter strip removal of cattle manure constituents in runoff. Transactions of the ASAE 41(5): 1375-1381.

Magette WL, Brinsfield RB, Palmer RE, Wood JD. 1989. Nutrient and sediment removal by vegetative filter strips. Transactions of the ASAE 32(2): 663-667.

Mankin KR, Barnes PL, Harner JP, Kalita PK, Boyer JE. 2006. Field evaluation of vegetative filter effectiveness and runoff quality from unstocked feedlots. Journal of Soil and Water Conservation 61(4): 209-217.

Mankin KR, Ngandu DM, Barden CJ, Hutchinson SL, Geyer WA. 2007. Grass-shrub riparian buffer removal of sediment, phosphorus, and nitrogen from simulated runoff. Journal of the American Water Resources Association 43(5): 1108-1116.

Mayer PM, Steven K. Reynolds J, Canfield TJ, McCutchen MD. 2005 Riparian buffer width, vegetative cover, and nitrogen removal effectiveness: areview of current science and regulations. Environmenta Protection Agency Document number EPA/600/R-05/118, US Government Printing Office, Washington, DC 20402-9328.

Minitab-Inc. 2006. Minitab statistical software, release 15 for windows. State College, Pennsylvania.

Muñoz-Carpena R, Parsons JE, Wendell GJ. 1999. Modeling hydrology and sediment transport in vegetative filter strips. Journal of Hydrology 214: $111-129$.

Muñoz-Carpena R, Parsons JE. 2005. VFSMOD-W Vegetative Filter Strips Hydrology and Sediment Transport Modeling System Model Documentation and Users Manual. University of Florida. Gainesville, FL. Available online at: http://carpena.ifas.ufl.edu/vfsmod/doc200/vfsmdraft.pdf.
Oost KV, Govers G, Desmet P. 2000. Evaluating the effects of changes in landscape structure on soil erosion by water and tillage. Landscape Ecology 15(6): 1572-9761.

Parajuli PB, Mankin KR, and Barnes PL. 2008. Applicability of targeting vegetative filter strips to abate fecal bacteria and sediment yield using SWAT. Agricultural Water Management 95: 1189-1200.

Parkyn S. 2004. Review of riparian buffer zone effectiveness. Technical Paper No: 2004/05. New Zealand Ministry of Agriculture and Forestry. Wellington, New Zealand.

Parsons JE, Gilliam JW, Muñoz-Carpena R, Daniels RB, Dillaha. TA. 1994. Nutrient and sediment removal by grass and riparian buffers. Environmentally Sound Agriculture Conference, Orlando, FL, USA.

Patty L, Real B, Gril JJ. 1997. The use of grassed buffer strips to remove pesticides, nitrate and soluble phosphorus compounds from runoff water. Pesticide Science 49(3): 243-251.

Quinn P, Beven K, Chevallier P, Planchon O. 1991. The prediction of hillslope flow paths for distributed hydrological modelling using digital terrain models. Hydrological Processes 5(1): 59-79.

Schäuble H. 2003. HydroTools 1.0 for ArcView 3.x. Version 1.0. Tübingen, Germany Available online at: http://www.terracs.com/html/hydro_ tools1.html.

Schmitt TJ, Dosskey MG, Hoagland KD. 1999. Filter strip performance and processes for different vegetation, widths, and contaminants. Journal of Environmental Quality 28(5): 1479-1489.

Sheridan JM, Lowrance R, Bosch DD. 1999. Management effects on runoff and sediment transport in riparian forest buffers. Transactions of the ASAE 42(1): 55-64.

Tingle CH, Shaw DR, Boyette M, Murphy GP. 1998. Metolachlor and metribuzin losses in runoff as affected by width of vegetative filter strips. Weed Science 46(4): 475-479.

USDA Soil Conservation Service. 1972. Section 4. Hydrology. In National Engineering Handbook. US. Department of Agriculture-Soil Conservation Service: Washington, DC.

USEPA. 1993. Paired watershed study design. Document 841-F-93-009, US Environmental Protection Agency, Washington, D.C.

Vache KB, Eilers JM, Santelmann MV. 2002. Water quality modeling of alternative agricultural scenarios in the US corn belt. Journal of the American Water Resources Association 38(3): 773-787.

Wenger S. 1999. A review of the scientific literature on riparian buffer width, extent and vegetation. Institute of Ecology, University of Georgia. Athens, GA.

Williams J. 1975. Sediment routing for agricultural watersheds. Water Resources Bulletin 11(5): 965-974.

Xiaoye L. 2008. Airborne LiDAR for DEM generation: some critical issues. Progress in Physical Geography 32(1): 31-49. 